\title{
A Literate Civilization
}

\section{Zaprulkhan}

IAIN Syaikh Abdurrahman Siddik Bangka Belitung, Indonesia

zaprulkhan_zahra@yahoo.co.id

\begin{abstract}
In the electronic age today, the internet continues to experience innovation and development. The internet is bringing people increasingly into a beautiful world without limits called the digital era. This is the special service that digital technology presents to humans in this era. The most popular icon of digital technology is social media. Social media rose to the top of the digital technology products that are the most popular among the world's people today. Popping up various kinds of social media: Facebook, Twitter, Google+, Instagram, Path, Pinterest, Tumblr, Flickr, WhatsApp and more. The number of social media users abounds. The graph rose sharply in a short time to reach billions. According to experts, the world of social media is like a double-edged knife. On the one hand, it can provide a huge benefit for people who can use it well. But on the other hand, it can also cause harm, a bad impact for people who are not able to use it properly, well, and appropriately. This paper will explore the benefits of literacy, which is actively writing through social media platforms in various forms.
\end{abstract}

Keywords; internet, literacy, writing, social media.

\begin{abstract}
Abstrak
Dalam the electronic age dewasa ini, internet terus mengalami inovasi dan pengembangan. Internet membawa manusia semakin dalam memasuki dunia indah tanpa batas yang disebut era digital. Inilah layanan istimewa yang dihidangkan teknologi digital pada manusia di era ini. Ikon terpopuler dari teknologi digital adalah media sosial (social media). Media sosial naik ke tangga teratas produk teknologi digital yang paling digemari masyarakat dunia saat ini. Bermunculan berbagai macam media sosial: Facebook, Twitter, Google+, Instagram, Path, Pinterest, Tumblr, Flickr, WhatsApp dan banyak lagi. Jumlah pengguna media sosial berlimpah ruah. Grafiknya naik tajam dalam tempo yang singkat hingga mencapai miliaran. Menurut para pakar, dunia media sosial itu ibarat pisau bermata dua. Pada satu sisi, ia bisa memberi memberi manfaat yang sangat besar bagi orang-orang yang dapat menggunakannya dengan baik. Tapi pada sisi yang lain, ia juga dapat menyebabkan mudharat, dampak yang buruk bagi orang-orang yang tidak mampu memanfaatkannya dengan benar, baik, dan tepat. Tulisan ini akan mengeksplorasi manfaat literasi, yakni aktif menulis melalui wahana media sosial dalam berbagai bentuknya.
\end{abstract}

Kata kunci; internet, literacy, writing, social media.

Received: 10-06-2019; accepted: 10-07-2019; published: 18-07-2019

Citation: Zaprulkhan, 'A Literate Civilization,' Mawa'izh, vol. 10, no. 1 (2019), pp. 171-189. 


\section{A. Pendahuluan}

enurut McLuhan hingga kini manusia telah menjalani empat periode perkembangan teknologi komunikasi-informasi. Masing-masing era memiliki corak komunikasi-informasi yang berbeda. Ini disebabkan faktor inovasi teknologi yang semakin canggih dari zaman ke zaman. Empat periode itu sebagai berikut.

Pertama, the Tribal Age. Ini era purba. Andalan manusia sepenuhnya indra pendengaran. Dengan indra itulah menusia menjalankan sistem komunikasinya. Perangkat fisik yang melekat pada dirinya itulah yang dioptimalkan untuk membangun komunikasi dengan sesama. Narasi, cerita, dongeng, dan tuturan adalah contoh bentuk komunikasi zaman ini. Jadi pada era ini, perangkat dan pola komunikasi yang digunakan masih sangat sederhana.

Kedua, the Age of Literacy. Era ini ditandai dengan ditemukannya alfabet atau huruf. Temuan ini mengubah total sistem dan pola komunikasi. Indra penglihatan menggeser fungsi indra pendengaran. Mata lebih dominan dibanding telinga. Di era ini, komunikasi yang dijalankan manusia tidak lagi mengandalkan tuturan, tapi lebih kepada tulisan. Disebut era literasi, membaca. Kultur literasi ini menandai terbukanya era baru yang lebih maju. Secara teknologis, pola komunikasi-informasi manusia sudah setingkat lebih canggih.

Ketiga, the Print Age. Di era ini teknologi komunikasi-informasi sudah semakin canggih. Ditandai dengan ditemukannya mesin cetak. Di era ini, pola komunikasi semakin efektif, efisien, dan luas jangkauannya. Mesin cetak mempermudah kerja manusia. Penggandaan tak lagi manual. Mesinlah yang menggandakan surat kabar, misalnya, bukan lagi tangan manusia. Tentu, produktivitasnya berlipat ganda. Jika tangan hanya memproduksi beberapa eksemplar surat kabar dalam sehari, mesin menggandakannya menjadi ratusan hanya dalam satu jam. Efeknya: posisi manusia mulai digeser oleh mesin. Buruh digantikan oleh mesin cetak.

Keempat, the Electronic Age. Era ini ditandai dengan ditemukannya berbagai macam alat atau teknologi komunikasi, seperti telegram, telepon, radio, film, televisi, komputer, dan puncaknya internet. Sistem komunikasi jauh lebih efisien, terintegrasi, dan cepat. Muncul istilah "global village". Karena teknologi yang dibuat manusia mampu menjangkau hingga lokasi terjauh bumi dalam tempo yang sesingkat-singkatnya. Maka 


\section{Mawaizh}

Jurnal Dakwah dan Pengembangan Sosial Kemanusiaan

Vol. 10, no. 1 (2019), pp. 171-189.

DOI: https://doi.org/10.32923/maw.v10i1.710

dunia menjadi seakan-akan kecil di mata manusia. Laksana sebuah "desa" saja. Era keempat inilah yang berlangsung di dunia saat ini. Di era ini, bahkan komputer dengan cepat menjadi barang "kuno". Baru beberapa tahun yang lalu komputer berbentuk kotak persegi yang besar dan berat, lalu dengan cepat berevolusi menjadi laptop mini. Kini sudah berevolusi lagi menjadi tablet kecil sebesar genggaman tangan manusia. Ini membuktikan, semakin hari, evolusi teknologi komunikasi-informasi semakin kilat. ${ }^{1}$

Dalam the electronic age dewasa ini, internet terus mengalami inovasi dan pengembangan. Internet membawa manusia semakin dalam memasuki dunia indah tanpa batas yang disebut era digital. Ini sebuah era di mana sistem dan perangkat teknologi bisa menghubungkan manusia yang satu dengan yang lainnya dalam sebuah "relasi" yang bersifat maya. Internet bertopang pada sistem yang bersifat maya. Istilah lainnya adalah cyberspace (ruang maya). Ruang ini tidak memiliki "tembok" pembatas. Batas tanpa sekat. Siapa masuk ke dalamnya, dapat menjelajah (browsing) sepuas mungkin. Seperti berselancar di laut tidak terbatas. Inilah layanan istimewa yang dihidangkan teknologi digital pada manusia di era ini.

Ikon terpopuler dari teknologi digital adalah media sosial (social media). Media sosial naik ke tangga teratas produk teknologi digital yang paling digemari masyarakat dunia saat ini. Bermunculan berbagai macam media sosial: Facebook, Twitter, Google+, Instagram, Path, Pinterest, Tumblr, Flickr, WhatsApp dan banyak lagi. Tapi, sama-sama penyedia layanan media sosial. Jumlah pengguna media sosial berlimpah ruah. Grafiknya naik tajam dalam tempo yang singkat. Jumlahnya kini mencapai miliaran.

Menurut para pakar, seperti Nicholas Carr $^{2}$ dan Daniel Goleman, ${ }^{3}$ dunia media sosial itu ibarat pisau bermata dua; Pada satu sisi, ia bisa memberi memberi manfaat yang sangat besar bagi orang-orang yang dapat menggunakannya dengan baik. Tapi pada sisi yang lain, ia juga dapat menyebabkan mudharat, dampak yang buruk bagi orang-orang yang tidak mampu memanfaatkannya dengan benar, baik, dan tepat. Tulisan ini akan mengeksplorasi manfaat literasi, dalam hal ini yakni aktif menulis melalui wahana media sosial dalam berbagai bentuknya.

\footnotetext{
${ }^{1}$ Fayakhun Andriadi, Demokrasi di Tangan Netizen (Jakarta: RMBOOKS, 2016), p. 32-4.

2 Lihat dalam Nicholas Carr, The Shallow, trans. by Rudi Atmoko (Bandung: Mizan, 2011).

${ }^{3}$ Lihat dalam Daniel Goleman, Focus (New York: Harper, 2013).
} 


\section{B. Pembahasan}

"The third wave does more than simply accelerate our information flows: it transforms the deep structure of information on which our daily actions depend" 4 . Statement di atas dilontarkan oleh futurolog tersohor abad ke-20, Alvin Toffler dalam karya cemerlangnya: The Third Wave. Dengan bukti-bukti yang begitu kaya dan "resourceful" Toffler menunjukkan secara eksploratif bahwa dalam gelombang ketiga kita memasuki era informasi yang mampu menyentuh seluruh aspek kehidupan kita, baik aspek eksternal maupun internal. Sebagaimana diisyaratkan dalam ungkapan Toffler di atas, fenomena gelombang ketiga bukan hanya mempercepat arus informasi yang kita terima, tapi gelombang ini juga mentransformasikan landasan struktur informasi yang selama ini menentukan perilaku sehari-hari kita.

Menurut Rhenald Kasali, ramalan Toffler tentang era informasi yang menyatukan minat tersebut, telah menggerakkan para pelaku, pioner, dan disruptor teknologi sehingga lahirlah internet. Steve Case, pendiri American Online (AOL) adalah salah satu ilmuwan yang terpengaruh tulisan Toffler. Ia membagi dunia internet yang tengah kita jalani ini ke dalam tiga gelombang.

- Gelombang Pertama (1985-1999)_From Zero to One

Terinspirasi pemikiran Toffler, para tokoh seperti Steve Jobs, Bill Gates, Steve Cace, Moore, Scott McNealy, dan Groove bergerak dan mengerahkan segala upaya ibarat para pembuka hutan yang membabat semak belukar untuk mewujudkan konektivitas internet. Mereka pun menghasilkan produk-produk untuk membuka akses seperti perangkat lunak dasar, modem, mikroprosesor, perangkat keras, dan jejaring yang memungkinkan terhubungnya hasil kerja mereka. Dan, pertanyaan media saat itu adalah: "Kira-kira seperti apa cara kerja alat ini? Siapa yang membutuhkannya?" Pemakai pertama produk-produk itu adalah pionir dan pehobi.

- Gelombang Kedua (2000-2015)-Aplikasi dan Komersialisasi

Ini adalah gelombang yang penuh keriaan setelah konektivitas terbentuk. Inilah saatnya cita-cita Toffler direalisasikan oleh para pembentuk komunitas. Kemunculan dan semakin kuatnya mesin pencari Google bukan saja mematikan Yellow Pages tetapi juga memperkuat komunitas dunia dalam mengorganisasi realitas, membentuk identitas, mencari teman, kekasih, barang, hiburan, tempat, informasi, dan lain-lain.

\footnotetext{
${ }^{4}$ Alvin Toffler, The Third Wave (New York: Bantam Books, 1979), h. 127.
} 
Selain Google, pada era ini juga marak berkembang media sosial, atau jejaring sosial yang berpotensi mengorganisasi diri kita. Pada gelombang ini pula muncul produk-produk yang lebih bersahabat, yang membuat manusia bisa berpindah dari alam fisik geografisnya ke dunia maya, mulai dari video, permainan, peta, perjalanan, dan komunikasi.

Untuk pertama kalinya, Apple pun mengintegrasikan kehidupan itu dalam ponsel, menjadi smartphone. Google pun meluncurkan Android. Hidup menjadi lebih smart, lebih mudah diakses, lebih mobile dan menjadi motor perkembangan ekonomi melalui e-commerce yang memicu perdagangan global. Tokoh-tokoh pada gelombang ini adalah Mark Zuckerberg, Larry Page, Jack Ma, Kevin Systrom, Chad Hurley, Steve Chang, Jawed Karim, Tim Cook, dan Sergey Brin.

- Gelombang Ketiga (2016) -Era Internet of Things

Inilah saatnya internet hidup mandiri dan tak lagi sekedar menjadi milik perusahaan-perusahaan perintis internet. Internet memungkinkan tercapainya kemajuan dalam bidang kesehatan, pendidikan, transportasi, keagamaan, perdagangan yang lebih sehat, dan masih banyak lagi. ${ }^{5}$

Disruption menjadi sesuatu yang tak terhindarkan. Pada tahapan ini muncullah plarform-platform baru seperti MOOC (Massive Open Online Course), ekonomi berbagi (sharing economy), online economy, peer to peer lending, smart home, fleet management, smar cities/kampong, surveillance, dan lain-lain. Ketika mesin-mesin telah lulus dalam ujian algoritma, internet kini masuk ke tahap yang lebih dalam dari yang telah kita singgung sebelumnya. Produknya begitu luas, mengisi celah-celah kehidupan kita dalam berbagai lini.

Pada intinya, internet bisa membuat semua yang menempel di tubuh kita, rumah, mobil, kota, industri, bandara, pakaian, hewan peliharaan, dan sebagainya menjadi amat cerdas karena terhubung dengan sensor dari internet secara sederhana. Internet juga mengubah gaya hidup, masyarakat, tranportasi, industri, ekonomi, dan keinsanian kita. Demikianlah inovasi ini bergerak, mewarnai dunia kita, memilih tararan sosial, membentuk disruption society, dan memaksa kita bekerja dan berpikir lebih cepat, degan disruptive mindset. ${ }^{6}$

${ }^{5}$ Rhenald Kasali, Disruption (Jakarta: Gramedia, 2016), p. 56-8.

6 Ibid., p. 60. 
Perubahan masif menjelma suatu keniscayaan. Perubahan masif ini pula yang disebut oleh Rhenald Kasali dalam buku mutakhirnya sebagai The Great Shifting, perubahan secara besar-besaran. Pertanyaan yang menggoda benak kita adalah apa sebenarnya disrupsi itu?

Disrupsi adalah sebuah inovasi. Inilah inovasi yang akan menggantikan seluruh sistem lama dengan cara-cara baru. Disruption berpotensi menggantikan pemainpemain lama dengan yang baru. Disruption menggantikan teknologi lama yang serba fisik dengan teknologi digital yang menghasilkan sesuatu yang benar-benar baru dan lebih efisien, juga lebih bermanfaat. ${ }^{7}$

Disrupsi juga terjadi karena ada orang-orang inovatif yang mengeksplorasi masa depan dan membawanya ke hari ini dengan teknologi, lalu mengubah seluruh platform dan kita menghadapinya dengan spirit "tomorrow is today".8 Lalu apa saja bentuk perubahan eksponensial tersebut? Saya ingin menayangkan sebagian bentuk perubahan yang dipaparkan Rhenald Kasali yang akan kita hubungkan dengan dunia literasi.

Pertama, teknologi, khususnya infokom, telah mengubah dunia tempat kita berpijak. Teknologi telah membuat segala produk menjadi jasa, jasa yang serba digital, dan membentuk marketplace baru, platform baru, dengan masyarakat yang sama sekali berbeda. Kedua, sejalan dengan itu muncullah generasi baru yang menjadi pendukung utama gerakan ini. Mereka tumbuh sebagai kekuatan mayoritas dalam peradaban baru yang menentukan arah masa depan peradaban. Itulah generasi millennials.

Ketiga, kecepatan luar biasa yang lahir dari microprocessor dengan kapasitas ganda setiap 24 bulan menyebabkan teknologi bergerak lebih cepat dan menuntut manusia berpikir dan bertindak lebih cepat lagi. Manusia dituntut untuk berpikir eksponensial, bukan linear. Manusia dituntut untuk merespons dengan cepat tanpa keterikatan pada waktu (menjadi 24 jam sehari, 7 hari seminggu) dan tempat (menjadi di mana saja), dengan disruptive mindset. ${ }^{9}$

Keempat, kehidupan dan bisnis akan berpindah secara massif ke dalam platfomr. Perpindahan kehidupan dari dunia lama ke platform tidak hanya terbatas

${ }^{7}$ Ibid., p. 34.

${ }^{8}$ Rhenald Kasali, The Great Shifting (Jakarta: Gramedia, 2018), p. iii.

${ }^{9}$ Rhenald Kasali, Disruption, pp. xix-xx. 


\section{Mawaizh}

Jurnal Dakwah dan Pengembangan Sosial Kemanusiaan

Vol. 10, no. 1 (2019), pp. 171-189.

DOI: https://doi.org/10.32923/maw.v10i1.710

pada aspek-aspek yang ramai dibicarakan (sektoral), melainkan juga pada cara, metode berusaha (dari owning economy ke sharing, dari product-baced ke platform, dari pendekatan tunggal ke ambidextrous), dan meluas menjadi multy-industry. Perubahan ini akan memaksa bangsa-bangsa untuk lebih giat meremajakan peraturan lama, membuat regulasi baru, serta mengubah cara pandang dalam pengelompokan industri dan penciptaan lapangan kerja baru. ${ }^{10}$

Kelima, pekerjaan-pekerjaan yang kita kenal abad 20, perlahan-lahan akan digantikan oleh pekerjaan-pekerjaan baru yang lebih berbasiskan teknologi. Pekerjaanpekerjaan lama akan tetap dibutuhkan sepanjang pelaku bisa memperkaya diri dengan aplikasi teknologi.

Keenam, tidak ada lagi tempat (dalam dunia kerja) bagi kelompok medioker yang kurang menuntut diri untuk belajar kembali atau bermental penumpang. Bahkan, ijazah perguruan tinggi terbaik pun tidak cukup untuk mengantarkan diri ke jenjang yang lebih tinggi bila penggemblengan mental diri tidak dilakukan.

Ketujuh, pendidikan akan mengalami tekanan besar perubahan dari cara pengajaran, teknologi, dan standar kualitas. Algoritma dan kecerdasan artifisial akan berpengaruh signifikan dalam proses pembelajaran. Kedepalan, pendekatan what to learn akan menjadi usang dan digantikan how to learn. ${ }^{11}$

Berdasarkan beberapa karakteristik disrupsi atau the great shifting tersebut, pertanyaan selanjutnya adalah apakah seluruh aspek kehidiupan kita akan mengalami perubahan eksponensial? Ternyata tidak. Ada beberapa aspek dari kehidupan kita yang tidak berubah atau tidak harus berubah. Pertama, kurva belajar (learning curve atau experience curve). Kurva belajar menandakan bahwa setiap hal baru selalu menyandang sisi lemahnya; belum kuat, belum bagus, belum cukup efisien, belum cukup memadai, belum bisa menguntungkan, dan masih banyak tingkat kesalahan yang merugikan, bahkan mengakibatkan jatuhnya korban. Namun, karakter manusia atau organisasi yang belajar adalah terus melakukan perbaikan. Segala yang baru itu menjadi lemah manakala masih dikembangkan dalam frame "product-based", dan baru menjadi kuat manakala kehidupan berhasil dibangun melalui pendekatan platform.

${ }^{10}$ Rhenald Kasali, Shifting, p. xix.

11 Ibid., pp. xix-xx. 
Kedua, cinta, kebaikan, kreativitas, dan kegigihan selalu dibutuhkan untuk menghadapi dunia baru ini. Cinta, kebaikan, kreativitas, dan kegigihan adalah hal yang tidak bisa digantikan oleh teknologi. Itulah kehidupan.

Ketiga, meskipun manusia saling meniru dan bisa saling menyamakan satu sama lain, tetap saja dibutuhkan keunikan. Keunikan akan menciptakan manfaat (value) yang dicari para pelanggan dan memberikan keuntungan untuk berkelangsungan.

Keempat, meskipun sesuatu berpindah, akan tetap ada ritual, adat istiadat, dan kebiasaan-kebiasaan yang bisa dipertahankan. Ia hanya bisa dipertahankan kalau manusia mampu membuatnya relevan. Yang berubah mungkin hanya alat dan metodenya. Walaupun bisa saja menggeser tradisi dan mengubah kebiasaan-kebiasaan.

Kelima, yang tidak berubah adalah kebutuhan dasar manusia (basic human need). Manusia dalam peradaban apapun selalu membutuhkan sandang, pangan, rasa aman, persahabatan, kebutuhan sosial, harga diri, pengakuan, serta aktualisasi diri. Meskipun wujud atau implementasinya menyesuaikan dengan teknologi dan perkembangan zaman, kebutuhan itu tetap ada.

Keenam, meskipun kehidupan baru telah lahir, itu tidak berarti bahwa yang lama akan habis sama sekali dan berakhir. Hadirnya sharing economy tidak dengan serta-merta membubarkan owning economy. Mereka bisa memudarkan, membuatnya usang, tetapi tidak menghilangkan. Namun, produk bisa saja berganti, demikian juga mereka yang sudah begitu kuat dan mengakar. Namun, dalam banyak hal, semua itu bisa saja saling menggantikan seperti smartphone Android dan iPhone yang menggantikan posisi ponsel Nokia atau seperti kamera digital yang menggantikan posisi rol film, begitu seterusnya. ${ }^{12}$

Sampai di sini, pertanyaan besar yang layak kita ajukan adalah bagaimana korelasi era disrupsi sebagai peluang dan tantangan bagi dunia literasi? Pertama, karena dunia sudah mengecil dan bahkan sudah berada dalam genggaman tangan kita (melalui smartphone misalnya), maka pertama kali yang perlu kita upgrade adalah cara berpikir kita. Kita perlu merubah cara kita memandang dunia atau mindset kita. Kita harus memperluas spektrum cakrawala berpikir kita. Kalau sebelumnya kita sudah merasa cukup dengan memiliki local mindset dan national mindset, hari ini kita harus memperluasnya dengan membangun global mindset.

12 Ibid., pp. xxxvii-viii. 
Tatkala memasuki era disrupsi, kita memasuki gelombang ketiga internet of things yang menyatukan seluruh umat manusia dalam sebuah dunia digital. Today we can connect with all people over the world without any boundaries. We are connected each other all the time without any distance. Sehingga kita bukan lagi hanya sebagai local citizenship tapi juga menjadi bagian dari global citizenship. Kita tidal lagi hanya sebagai national citizenship tapi juga sebagai the world citizenship. Melalui dunia internet, kita bukan lagi hanya menjadi negara lokal Indonesia, tapi juga sudah menjadi warga negara dunia. Dengan kesadaran ini, artinya kita perlu memiliki mondial mindset, cakrawala berpikir yang mendunia; horizon perspektif yang menyemesta.

Ilustrasinya begini, sebagai penduduk Pangkalpinang-Bangka misalnya, saya mempunyai tahapan kesadaran lokal-nasional seperti ini: Saya adalah warga masyarakat Pangkalpinang, warga masyarakat Bangka dan warga masyatakat Kepulauan Bangka Belitung. Titik. Ketika kesadaran saya berhenti pada level lokal provinsi Kepulauan Bangka Belitung, maka semua tindakan saya hanya akan saya sadari memiliki dampak pada level Bangka Belitung. Ketika saya memperluas jangkauan kesadaran mindset saya sampai pada level nasional: Saya sebagai warga negara Indonesia misalnya, semua perbuatan yang saya lakukan hanya akan membawa dampak dalam konteks keindonesiaan. Itu yang saya sadari dengan minset lokal dan nasional yang saya miliki.

Tetapi ceritanya menjadi lain, ketika saya telah mempunyai kesadaran global dengan menyadari bahwa diri saya sebagai bagian dari global citizenship. Sebagai bagian dari the world citizenship. Walaupun secara geografis, saya sebagai penduduk Pangkalpinang, sebagai warga masyarakat Kepulauan Bangka Belitung, dan sebagai warga negara Indonesia, tapi sebagai warganet dan netizen, saya telah menjadi warga dunia. Sebagai netizen, saya memiliki identitas sebagai the world citizenship.

Dengan kesadaran global citizenship ini, ketika saya berselancar di internet saya akan mempertimbangkan komunitas global. Ketika ujung jari-jemari saya menyentuh layar tablet atau smartphone untuk melontarkan sebuah statemen, menulis suatu opini atau artikel, saya akan mempertimbangkan bagaimana caranya agar artikel yang saya posting dapat diakses oleh warganet atau netizen seluas-luasnya.

Di sini saya tidak tercerabut dari akar kultur lokal dan nasional saya sebagai local and national citizenship. Tetapi saya juga menyadari bahwa kini saya merupakan 


\section{Mawaizh}

Jurnal Dakwah dan Pengembangan Sosial Kemanusiaan

Vol. 10, no. 1 (2019), pp. 171-189.

DOI: https://doi.org/10.32923/maw.v10i1.710

bagian dari the world citizenship. Sehingga ketika berinteraksi dalam jejaring media sosial idealnya kita melakukan strategi ini: How to combine between local citizenship and global citizenship; How to combine between national citizenship and the world citizenship. Kita harus menyelaraskan kewargaan diri kita secara seimbang antara warga negara lokal dengan warga negara global, dengan warga negara dunia.

Dengan strategi ganda ini, efeknya menjadi sangat dahsyat. Literasi yang kita lakukan sudah melampaui konteks lokal dan nasional yakni dengan menembus level global. Walaupun kita tidak pernah tahu secara pasti pengaruh dari artikel-artikel yang kita posting di media sosial, tapi dengan kesadaran global tersebut, tulisan-tulisan kita pasti meninggalkan jejak-jejak pengaruh tersendiri. Itu yang saya alami sehingga bisa berkomunikasi dengan netizen dari manca negara, seperti dari Malaysia, Brunei, Filipina, Thailand, Mesir, Turki, Australia, bahkan Amerika. Meskipun kecil tetap ada riak-riak gelombang yang menyapa masyarakat global yang sedang berenang ditengahtengah samudera dunia maya.

Kedua, karena gelombang ketiga internet of things selalu melakukan pergerakan perubahan secara eksponensial, maka dalam berliterasi kita dituntut untuk selalu memperkaya pikiran kita dengan wawasan dan ide-ide mutakhir. Dengan kata lain, kita harus bersedia untuk terus-menerus belajar. Kita harus bersedia menjadi seorang an eternal learner, seorang pembelajar abadi. Seorang pembelajar yang memiliki kedahagaan ontologis: sebuah gairah keilmuan yang tidak pernah terpuaskan. Hari ini, kita harus memiliki sebuah ketidakpuasan konstruktif. Kita tidak boleh merasa cukup dengan ilmu pengetahuan yang telah kita miliki. Saat ini, kita tidak bisa lagi merasa puas dengan kecerdasan dan kepandaian, dengan skill dan kompetensi yang sudah kita kuasai. Kita harus senantiasa membuka diri dengan puspa ragam ilmu pengetahuan yang terus berkembang.

Dalam konteks ini, setidaknya ada dua syarat yang perlu kita miliki yaitu grass root understanding dan world class competence. Dengan grass root understanding, kita tetap mampu memahami berbagai problematika pada level lokal-nasional. Sehingga dalam berliterasi kita tetap sanggup merespons berbagai persoalan-persoalan lokal secara kontekstual sekaligus menyuguhkan solusi-solusi yang relevan. Tanpa grass root understanding, kita akan kehilangan konteks lokal-nasional dalam berliterasi. Melalui grass root understanding inilah kita tetap berakar kokoh pada tradisi tempat kita 
berpijak, sehingga wacana literasi yang selalu kita suarakan akan bergema kepada orang-orang di sekeliling kita.

Tapi grass root understanding saja tidak cukup. Kita harus melengkapinya dengan world class competence, kompetensi kelas dunia. Tentu saja yang dimaksud dengan world class competence tidak harus pada puncak idealismenya, meskipun tidak menutup kemungkinan untuk mencapai titik idealisme tersebut. Praktisnya begini: Kalau kompetensi kita dalam bidang tafsir, maka idealnya kita bukan hanya menguasai wacana tafsir konteks Indonesia, seperti tafsir Al-Azhar-nya Hamka dan Al-Misbah Quraish Shihab misalnya, tapi juga memahami beragam corak tafsir para ulama dari kawasan Timur Tengah dan sebagain ilmuwan Barat Eropa yang menghasilkan produk tafsir.

Kita bukan cuma mengerti, mengkaji dan mendalami tafsir Al-Jami' Li Ahkamil Quran karya Imam Qurthubi, dan Jami'ul Bayan 'an Ta'wil Ayil Quran, karya Imam Thabari. Tafsir Mafatihul Ghaib karya Fakhruddin Ar-Razi dan tafsir Al-Kasyaf-nya Zamaksyari, tapi juga menelaah dan memahami tafsir semacam The Message of the Quran-nya Muhammad Asad, The Holy Quran-nya Muhammad Yusuf Ali, dan The Holy Quran-nya Mualana Muhammad Ali misalnya.

Jika kompetensi kita dalam bidang pendidikan, maka kita bukan cuma menguasai wacana pendidikan yang digulirkan oleh Ki Hajar Dewantoro, Kyai Hasyim Asyari dan Kyai Ahmad Dahlan, tapi juga mengerti pemikiran pendidikan ilmuwan muslim manca negara seperti, Imam Ghazali dan Muhammad Iqbal, Fazlur Rahman dan Naquib Al-Attas, sekaligus memahami sebagian wacana pendidikan dari para ilmuwan Barat-Eropa semacan John Dewey, Ivan Illich, dan Paulo Freire misalnya.

Bila kompetensi kita dalam bidang filsafat Islam, misalnya, maka kita dituntut bukan hanya menguasai pelbagai aliran filsafat Islam, seperti teologi dialektik dan peripatetisme, iluminisme, teosofi dan filsafat hikmah, tapi juga sedikit banyak mengerti wacana filsafat Barat-Eropa seperti rasionalisme dan empirisme, kritisisme dan eksistensialisme, hingga aliran filsafat strukturalisme dan post-strukturalisme, fenomenologi dan hermeneutika, dekonstruksi dan teori kritis, misalnya.

Jadi, meminjam bahasa Muhammad Yunus dalam Banker to The Poor, dengan grass root understanding kita menerapkan the worm's eye view; Kita menggunakan sudut pandang seekor cacing yang langsung bergumul dengan berbagai problematika 
tempat kita berpijak. Sedangkan dengan world class competence, kita mengaplikasikan $a$ bird's eye view. Artinya kita memiliki perspektif strategis yang jauh ke depan dan memahami sedikit banyak masalah-masalah global yang relevan dengan kompetensi keilmuan kita. ${ }^{13}$

Dengan kompetensi holistik ini, ketika kita menggulirkan wacana melalui tulisan dalam bidang tafsir, pendidikan, dan filsafat, maka wacana yang kita suarakan bukan cuma bergema dalam konteks lokal-nasional, tapi juga mampu bergaung dalam konteks global-internasional. Wacana yang kita narasikan tidak lagi hanya menjadi konsumsi pada level nasional, tapi juga mampu diakses oleh masyarakat level internasional. Spektrum jangkauan literasi yang kita perankan mampu menembus masyarakat global, karena kita tidak hanya memiliki grass root understanding, tapi juga telah menggenggam kunci world class competence.

Ketiga, karena sebagian besar umat manusia kini berkomunikasi dan berinteraksi melalui dunia digital dan media sosial, seperti Line, Instagram, Twitter, WhatsApp, dan Facebook misalnya, maka kita harus aktif berliterasi melalui beragam saluran dalam jejaring media sosial tersebut. Sebab sekali kita menggulirkan wacana di media sosial, gagasan-gagsan kita akan diakses oleh netizen yang begitu luas dengan latar belakang pendidikan, budaya, sosial, ekonomi, usia, minat, keyakinan dan agama yang amat beragam.

Katakanlah kita memposting sebuah tulisan ringan di wall facebook kita. Kemudian di antara sebagian mereka ada yang men-share tulisan kita melalui Facebook dan ke beberapa grup WhatsApp. Selanjutnya melalui beberapa grup WhatsApp ini, tulisan kita menyebar semakin luas lagi ke bebberapa grup WhatsApp lainnya. Akhirnya, boleh jadi tulisan sederhana yang kita posting itu kini menjadi viral. Ide-ide yang kita gulirkan dalam tulisan tersebut, menjadi perbincangan bukan hanya di dunia maya, tapi sudah merambah dunia nyata.

Bermula dari cuma ratusan netizen yang menyimak tulisan kita dan ada beberapa di antara mereka yang membagikannya, kini tulisan kita sudah diakses oleh ribuan netizen yang aktif di dunia media sosial. Dari cuma ratusan orang, kini tulisan kita telah menyentuh benak ribuan warganet. Dari sentuhan hanya terhadap ratusan orang, kini kita telah mampu menorehkan jejak pengaruh kebaikan (dari ide-ide positif

\footnotetext{
${ }^{13}$ Muhammad Yunus, Banker to The Poor (New York: Public Affairs, 1999), p. ix.
} 


\section{Mawaizh}

Jurnal Dakwah dan Pengembangan Sosial Kemanusiaan

Vol. 10, no. 1 (2019), pp. 171-189.

DOI: https://doi.org/10.32923/maw.v10i1.710

yang ada dalam tulisan kita) kepada ribuan orang. Dari jejak-jejak pengaruh kebaikan di dunia maya, kini kita telah benar-benar menebarkan pengaruh kebaikan dalam dunia nyata pula.

Kita bisa melihat fenomena menyebarnya ide-ide yang menorehkan jejak pengaruh secara spektakuler ini pada figur-figur seperti Sumanto Qurthuby, Nadirsyah Hosen dan Denny Siregar, misalnya untuk menyebut segelintir nama yang sangat populer saat ini. Sekali mereka memposting sebuah tulisan, ada ribuan netizen yang menyimak dan menyukai tulisan mereka. Kemudian ada ratusan netizen yang membagikan tulisan mereka melalui berbagai saluran digital, baik melalui facebook, blog-blog website maupun melalui WhatsApp. Dalam tataran tertentu, hampir setiap tulisan yang mereka posting selalu berpotensi untuk menjadi viral setidaknya di kalangan follower mereka sendiri yang berjumlah puluhan ribu audiens.

Yang menakjubkan, untuk tulisan dan artikel-artikel yang mereka posting di media sosial dicetak dalam bentuk buku, semua buku mereka selalu menjadi best seller. Ini bisa kita lihat buku karya Sumanto Qurthuby: Islam, Arab dan Indonesia, kuliah virtual facebook, yang sampai kini sudah terbit sampai empat seri, menjadi semacam tetralogi. Walaupun keempat buku tersebut sangat tebal-tebal, hampir 500 halaman, namun semuanya tetap laris manis. ${ }^{14}$

Nadirsyah Hosen dengan buku Tafsir Al-Qur'an di Medsos, ${ }^{15}$ Islam Yes, Khilafah No jilid 1 dan jilid 2,16 serta karya terbarunya: Saring Sebelum Sharing. Semuanya langsung menjadi best seller di pasaran. Demikian pula dengan Denny Siregar. Sejak karya pertamanya yang berasal dari postingan tulisan-tulisannya di Facebook diterbitkan, seperti Tuhan Dalam Sekangkir Kopi. ${ }^{17}$ Kemudian berlanjut terbit buku: Bukan Manusia Angka, ${ }^{18}$ Semua Melawan Ahok, ${ }^{19}$ hingga karya terbarunya: The Art of War. ${ }^{20}$ Lagi-lagi seluruhnya menjadi karya-karya best seller nasional.

\footnotetext{
14 Sumanto Qurthuby, Islam, Arab dan Indonesia 1 (Semarang: eLSA Press, 2016); Islam, Arab dan Indonesia 2 (Semarang: eLSA Press, 2017); Islam, Arab dan Indonesia 3 (Semarang: eLSA Press, 2017); Islam, Arab dan Indonesia 4 (Semarang: eLSA Press, 2018).

15 Nadirsyah Hosen, Tafsir Al-Quran di Medsos (Jakarta: Bunya, 2017).

${ }^{16}$ Nadirsyah Hosen, Islam Yes, Khilafah No, Jilid 1 (Yogyakarta: UIN SUKA Pres, 2018) \& Islam Yes, Khilafah No, Jilid 2 (Yogyakarta: UIN SUKA Pres, 2018).

17 Denny Siregar, Tuhan Dalam Secangkir Kopi ( Jakarta: Noura, 2016).

18 Denny Siregar, Bukan Manusia Angka (Jakarat: Mitra Medika Mustika, 2017).

${ }^{19}$ Denny Siregar, Semua Melawan Ahok (Jakarat: Mitra Medika Mustika, 2018).

20 Denny Siregar, The Art of War (Jakarat: Mitra Medika Mustika, 2018).
} 
Yang lebih menakjubkan lagi, setelah tulisan-tulisan mereka terbit dalam bentuk buku, mereka diundang ke berbagai pertemuan untuk membedah gagasangagasan yang telah mereka gulirkan. Baik di kampus-kampus, pesantren-pesantren, yayasan-yayasan, sekolah-sekolah maupun kelompok-kelompok diskusi, dan pengajian non-formal mengundang mereka untuk mendiskusikan ide-ide yang telah mereka sebarkan, baik melalui media sosial maupun melalui bentuk buku. Mereka mengadakan semacam road show keliling Nusantara dalam rangka mensosialisasikan gagasan mereka di dunia nyata. Dari gagasan-gagasan sederhana yang mereka semai di dunia media sosial, kini gagasan-gagasan tersebut telah menyebar di dunia faktual. Saat ini, mereka bukan cuma benar-benar eksis di dunia maya, tapi juga eksis di dunia nyata.

Dalam era internet of things gelombang ketiga dewasa ini, kita bisa menyebut mereka sebagai influencer yakni orang-orang yang mempunyai follower atau audience sangat banyak di media sosial sekaligus juga mempunyai pengaruh yang sangat kuat terhadap follower mereka. Dan pengaruh itu bukan hanya bergema pada level dunia maya, tapi juga telah benar-benar membumi dalam dunia nyata.

Inilah salah satu peluang positif yang sangat dahsyat dari media sosial di era disrupsi: gagasan-gagasan yang kita semai di media sosial bukan lagi hanya bergema secara luas di media sosial semata, tapi juga mampu membawa dampak konkret terhadap kehidupan nyata secara faktual. Karena itu, pesannya bagi siapapun pegiat literasi: kita harus aktif menyemai gagasan-gagasan kita ke dalam ranah media sosial, entah melalui Twitter, blog, WhatsApp, maupun Facebook.

Keempat, meskipun era disrupsi menciptakan perubahan secara eksponensial, namun sebagaimana disinyalir oleh Rhenald Kasali, tetap ada beberapa aspek dalam kehidupan kita yang tidak serta merta berubah secara total. Begitu pula meskipun pelbagai bentuk kreativitas dan inovasi baru lahir secara massif, semua itu tidak berarti bahwa yang lama akan hilang, punah, dan tidak dibutuhkan lagi.

Hadirnya beragam perangkat digital yang dapat digunakan dalam berliterasi, tidak langsung melenyapkan gairah literasi dalam bentuk dunia perbukuan. Munculnya inovasi kreatif dari beberapa penerbit, seperti Gramedia Pustaka Utama, Mizan, dan Raja Grafindo Persada dalam melakukan digitalisasi buku-buku yang mereka terbitkan, tidak serta merta menghapuskan penerbitan buku-buku secara manual. 
Dari aspek konsumen, sebagian orang-orang yang sudah menikmati dalam membaca buku, setidaknya ada dua alasan besar mengapa masih membutuhkan bukubuku dalam bentuk printout: (1) ketika membaca buku, mereka telah memiliki kebiasaan menggumuli ide-ide yang ada dalam buku tersebut dengan berbagai cara. Entah dengan menggarisbawahi ide-ide penting atau gagasan-gagasan baru, memberi stabilo wacana-wacana yang sangat menarik, memberi catatan-catatan langsung pada margin kiri dan kanan, atas dan bawah buku yang kosong, atau dengan membuat kodekode khusus sesuai dengan keinginan kita.

Saya sendiri mempunyai pengalaman seperti itu dalam membaca buku. Sewaktu membaca buku, saya selalu menandai ide-ide penting atau gagasan-gagasan baru dengan stabilo, memberi tanda-tanda khusus yang berhubungan dengan style tulisannya maupun substansi gagasannya, memberi catatan-catatan khusus mengenai gagasan yang terkait dengan gagasan lain yang terdapat pada buku-buku yang sudah saya baca sebelumnya; atau pun memberi catatan kritis terhadap ide-ide yang terdapat pada buku yang sedang saya baca. Semua respons tersebut, saya tulis secara langsung di tengah-tengah kegiatan membaca buku tersebut. Kegiatan membaca seperti ini, bagi saya memberikan semacam "enjoyment of reading" atau "jouissance of reading", sebuah kenikmatan membaca yang luar biasa yang tidak bisa kita dapatkan ketika membaca wacana-wacana pemikiran dalam format $e$-book.

Ternyata, ketika saya ngobrol-ngobrol dengan sebagian kawan-kawan yang senang membaca, sense jouissance of reading ini dirasakan juga oleh mereka sewaktu membaca buku secara manual. Kenikmatan dalam menggarisbawahi, menandai dengan stabilo, memberi catatan-catatan langsung, mencoret pena di sana-sini, bahkan menyentuh dan membalik lembar demi lembar halaman buku yang sedang kita baca tersebut, membangkitkan sebuah kenikmatan yang tidak kita temukan dalam file-file berbentuk e-book. Walaupun file e-book sangat praktis dan portable kemana pun kita pergi, tapi tetap tidak bisa menorehkan jouissance of reading yang kita dapatkan pada buku-buku secara manual.

(2) Selanjutnya adalah alasan kesehatan. Lazimnya, orang-orang yang sudah memasuki usia 40 tahun, mudah terkena semacam kelelahan mata. Ketika kita membaca buku-buku dalam bentuk e-book, biasanya mata kita sudah tidak tahan dengan efek radiasi sinar biru dari layar tablet, handphone atau smartphone kita. Kita 


\section{Mawaizh}

Jurnal Dakwah dan Pengembangan Sosial Kemanusiaan

Vol. 10, no. 1 (2019), pp. 171-189.

DOI: https://doi.org/10.32923/maw.v10i1.710

tidak bisa lagi (tidak kuat) membaca e-book dengan berlama-lama. Paling lama antara satu sampai dua jam, umumnya mata kita sudah merasa kelelahan. Itulah alasannya mengapa, cukup banyak orang-orang yang mencetak kembali file-file $e$-book mereka dalam bentuk buku.

Sebab di samping untuk mendapatkan sense jouissance of reading, kedua mata mereka sudah tidak tahan lagi menatap layat smartphone dengan agak lama ketika membaca file e-book. Itulah pengalaman yang saya alami dan sebagian para penikmat buku lainnya yang sudah memasuki usia 40 tahunan. Ini artinya dunia perbukuan tidak akan hilang dari dunia perbisnisan dan kita sebagai penggiat literasi tetap bisa aktif menulis buku. Masa depan kita sebagai penulis buku tidak akan lenyap. Idealnya kita harus bergerak secara seimbang: aktif menulis melalui sarana media sosial dengan beragam fiturnya, sekaligus tetap aktif menulis dalam bentuk buku.

Akan tetapi terlepas dari semua itu, karena efek media sosial dengan kecepatan diseminasinya, keluasan daya jangkauan, dan sifat spontanitasnya yang sangat dahsyat, barangkali kita perlu meletakkan stressing point tulisan kita pada media sosial. Sebab sekali kita meng"klik" tulisan kita melalui wahana media sosial, saat itu juga tulisan kita bisa diakses oleh puluhan ribu netizen tanpa lagi terikat dalam batasan-batasan secara geografis. Ini benefit istimewa yang tidak dapat kita jangkau oleh buku. Di sini mau tidak mau, kita memang harus mengakui keistimewaan media sosial yang tidak dimiliki oleh buku dan sudah sewajarnya kalau kita memprioritaskan gerakan literasi kita pada ranah media sosial tersebut.

\section{Penutup}

Sebagaimana di awal tulisan ini, saya mengawalinya dengan kutipan dari Alvin Toffler, di penghujung tulisan ini pun izinkan saya mengakhirinya dengan merunkan kembali insight dari futurolog tersohor tersebut. Masih dalam buku yang sama, di bagian pemungkas The Third Wave, Toffler menulis demikian: "Some generations are born to create, others to maintain a civilization"21; "Ada generasi yang lahir untuk menciptakan sebuah peradaban, dan ada pula yang bertugas memelihara peradaban tersebut."

${ }^{21}$ Toffler, The Third Wave, p. 440. 
Pertanyaannya: Siapakah generasi yang mampu menciptakan peradaban? Secara ekplisit, Toffler mensinyalir bahwa di masa depan, yakni dewasa ini, orang-orang yang mampu menciptakan peradaban adalah orang-orang yang menguasai informasi secara digital, orang-orang yang menguasai fenomena internet of things, orang-orang yang mampu menggunakannya secara positif-konstruktif sekaligus kreatif-inovatif. Mereka tentu saja para innovators dalam ranah digital yang telah merubah dan merombak cara berkomunikasi miliaran umat manusia dewasa ini.

Kita bisa menyebut Sergey Brin dan Larry Page dengan mesin pencari Googlenya. Jerry Yang dan David Filo dengan Yahoo-nya. Bill Gates dengan perangkat lunak Microsof-nya. Steve Jobs sang pendiri Apple Inc dengan terobosan spektakuler perupa iPad, iTunes dan iPhone-nya. Jack Dorsey, Evan William dan Biz Stone dengan kreasi Twitter-nya. Kevin Systrom dan Mike Krieger dengan inovasi Instagramnya. Mark Zuckerberg dengan perangkat Facebook-nya. Serta Jan Koum dan Brian Acton dengan terobosan wahana komunikasi interaktif yang dapat menampilkan komunikasi secara tekstual, audio, sekaligus visual berupa WhatsApp. ${ }^{22}$

Secara akumulatif, mereka-lah para pencipta peradaban dalam ranah digital, dengan keunikannya masing-masing, yang akhirnya membawa dampak pada ranah realitas secara faktual. Tapi apakah hanya para kreator, inovator dan para raksasa dalam ranah digital itu yang bisa menciptakan peradaban?

Menurut Alvin Toffler ternyata tidak. Dalam prediksi Toffler, siapapun yang sanggup menguasai dan mengolah informasi secara positif-konstruktif sekaligus kreatifinovatif, niscaya orang-orang seperti itu akan mampu memberikan kontribusi terhadap peradaban masa depan. Tatkala kita mampu mengolah informasi dalam ranah internet of things dengan pelbagai wahana perangkat lunaknya secara kreatif-inovatif, kata Toffler: we have a destiny to create, kita telah dilahirkan untuk menciptakan peradaban.

Tepat pada poin inilah, di samping menulis buku secara manual, kita harus aktif menyemaikan ide-ide kita secara tertulis melalui puspa ragam perangkat yang tersedia dalam media sosial. Sesuai dengan kompetensi kita masing-masing, kita tetap harus menulis secara kreatif di media sosial. Bahkan sesuai dengan keunikan kita masingmasing, kita juga harus berupaya menggulirkan ide-ide tulisan kita secara inovatif 
dalam berbagai jejaring sosial, baik lewat Instagram, blog pribadi, Twitter, WhatsApp, maupun Facebook misalnya.

Dalam konteks Indonesia yang masih amat lemah budaya literasinya, tatkala masing-masing kita secara aktif bergerak dalam dunia literasi, baik dalam media sosial maupun dalam ranah faktual, kita laksana menyalakan lilin-lilin kecil di tengah-tengah kegelapan. Barangkali nyala lilin-lilin kecil kita tidak mampu memberikan penerangan yang cukup. Tapi sebagaimana diramalkan oleh Toffler, kalau kita tetap bertahan dalam mengolah informasi secara kreatif melalui wacana literasi, we have a destiny to create a literate civilization, a literate country, a literate nation; Kita telah ditakdirkan untuk memberikan sumbangsih sebagai bagian dari pencipta sebuah peradaban literasi, sebuah bangsa yang terpelajar, sebuah bangsa yang cerdas dan terdidik. Dan dalam era disrupsi hari ini, semua itu berada dalam ruang kemungkinan! 


\section{DAFTAR PUSTAKA}

Andriadi, Fayakhun. Demokrasi di Tangan Netizen. Jakarta: RMBOOKS, 2016.

Carr, Nicholas. The Shallow. Terj. Rudi Atmoko. Bandung: Mizan, 2011.

Goleman, Daniel. Focus. America: Harper, 2013.

Hosen, Nadirsyah. Tafsir Al-Quran di Medsos. Jakarta: Bunyan, 2017/ . Islam Yes, Khilafah No, Jilid 1. Yogyakarta: UIN SUKA Pres, 2018. . Islam Yes, Khilafah No, Jilid 2. Yogyakarta: UIN SUKA Pres, 2018 . Saring Sebelum Sharing. Yogyakarta: Bentang, 2019.

Isaacson, Walter. The Innovator. Terj. Reni Indarni. Yogyakarta: Bentang, 2015. Kasali, Rhenald. Disruption. Jakarta: Gramedia, 2016. . The Great Shifting. Jakarta: Gramedia, 2018. . Tomorrow Is Today. Bandung: Mizan, 2017.

Siregar, Denny. Tuhan Dalam Secangkir Kopi. Jakarta: Noura, 2016. . Bukan Manusia Angka. Jakarat: Mitra Medika Mustika, 2017. . Semua Melawan Ahok. Jakarat: Mitra Medika Mustika, 2018. . The Art of War. Jakarta: Mitra Medika Mustika, 2018.

Sumanto Qurthuby. Islam, Arab dan Indonesia 1. Semarang: eLSA Press, 2016. . Islam, Arab dan Indonesia 2. Semarang: eLSA Press, 2017. . Islam, Arab dan Indonesia 3. Semarang: eLSA Press, 2017. . Islam, Arab dan Indonesia 4. Semarang: eLSA Press, 2018.

Toffler, Alvin. The Third Wave. New York: Bantam Books, 1979.

Yunus, Muhammad. Banker to The Poor. New York: Public Affairs, 1999. 